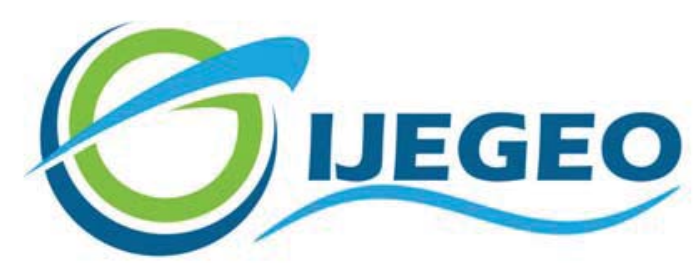

International Journal of Environment and Geoinformatics (IJEGEO) is an international, multidisciplinary, peer reviewed, open access journal.

\title{
Bed load transport estimations in Goodwin creek using neural network methods
}

\section{Murat AKSEL., Mehmet DIKICI., Sevket COKGOR}

\author{
Chief in Editor
}

Prof. Dr. Cem Gazioğlu

Co-Editors

Prof. Dr. Dursun Zafer Şeker, Prof. Dr. Şinasi Kaya,

Prof. Dr. Ayşegül Tanık and Assist. Prof. Dr. Volkan Demir

Editorial Committee (June 2021)

Assoc. Prof. Dr. Abdullah Aksu (TR), Assit. Prof. Dr. Uğur Algancı (TR), Prof. Dr. Bedri Alpar (TR), Assoc. Prof. Dr. Aslı Aslan (US), Prof. Dr. Levent Bat (TR), Prof. Dr. Paul Bates (UK), İrşad Bayırhan (TR), Prof. Dr. Bülent Bayram (TR), Prof. Dr. Luis M. Botana (ES), Prof. Dr. Nuray Çağlar (TR), Prof. Dr. Sukanta Dash (IN), Dr. Soofia T. Elias (UK), Prof. Dr. A. Evren Erginal (TR), Assoc. Prof. Dr. Cüneyt Erenoğlu (TR), Dr. Dieter Fritsch (DE), Prof. Dr. Çiğdem Göksel (TR), Prof.Dr. Lena Halounova (CZ), Prof. Dr. Manik Kalubarme (IN), Dr. Hakan Kaya (TR), Assist. Prof. Dr. Serkan Kükrer (TR), Assoc. Prof. Dr. Maged Marghany (MY), Prof. Dr. Michael Meadows (ZA), Prof. Dr. Nebiye Musaoğlu (TR), Prof. Dr. Masafumi Nakagawa (JP), Prof. Dr. Hasan Özdemir (TR), Prof. Dr. Chryssy Potsiou (GR), Prof. Dr. Erol Sarı (TR), Prof. Dr. Maria Paradiso (IT), Prof. Dr. Petros Patias (GR), Prof. Dr. Elif Sertel (TR), Prof. Dr. Nüket Sivri (TR), Prof. Dr. Füsun Balık Şanlı (TR), Prof. Dr. Uğur Şanlı (TR), Duygu Ülker (TR), Prof. Dr. Seyfettin Taş (TR), Assoc. Prof. Dr. Ömer Suat Taşkın (TR), Assist. Prof. Dr. Tuba Ünsal (TR), Dr. Manousos Valyrakis (UK), Dr. İnese Varna (LV), Dr. Petra Visser (NL), Prof. Dr. Selma Ünlü (TR), Assoc. Prof. Dr. Oral Yağcı (TR), Prof. Dr. Murat Yakar (TR), Assoc. Prof. Dr. İ. Noyan Yılmaz (AU); Assit. Prof. Dr. Sibel Zeki (TR) 


\title{
Bed load transport estimations in Goodwin creek using neural network methods
}

\author{
Murat Aksel $^{1 *}$, (D) Mehmet Dikici ${ }^{1}$, (D) Sevket Cokgor $^{2}$ (I) \\ ${ }^{1}$ Department of Civil Engineering, Faculty of Engineering, Alanya Alaaddin Keykubat University, Antalya, Turkey \\ ${ }^{2}$ Department of Civil Engineering, Faculty of Civil Engineering, Istanbul Technical University, Istanbul, Turkey \\ * Corresponding author: Murat Aksel \\ E-mail: murat.aksel@alanya.edu.tr
}

Received 10 Sept 2020

Accepted 28 Dec. 2020

How to cite: Aksel, M., Dikici, M., Cokgor, S., (2021). Bed load transport estimations in Goodwin creek using neural network methods.

International Journal of Environment and Geoinformatics (IJEGEO), 8(2):200-000. doi. 10.30897/ijegeo.794723

\begin{abstract}
Equations used for calculating bedload transport rates are generally developed based on the assumption of steady flow conditions. This implies that the relationship between bedload transport, discharge, flow depth, and shear stress is single-valued. One of the reasons for adopting such an approach is that almost all the pertinent laboratory data on bedload transport have been obtained from experiments performed under steady flow conditions. Similarly, the scarcity of accurate bed load field data obtained during the passage of floods is attributed to the difficulties, which at times can become life-threatening, encountered under such conditions. Provision of data under challenging conditions may lead to the inability to provide data in some cases and interruption in data continuity. It is difficult to make predictions using classical statistical science in discontinuous or lack of data situations. Artificial neural networks (ANN) are useful in predicting when the data is insufficient. In this study, two frequently used ANN applications, radial basis functions, and generalized regression neural network are employed to estimate the bed load data. It was seen that the ANN estimations are more satisfactory compared to those of the conventional statistical methods results. It was shown that ANN estimations for gravel bedload data are more successful than the sand load data.
\end{abstract}

Keywords: Bedload transport, artificial neural network, flow, creek

\section{Introduction}

When the value of the average shear stress of a riverine channel exceeds the bed material's critical shear stress, the particles on the bed physically begin to move in the flow direction. The particles follow arbitrary paths depending on flow conditions, the ratio of the fluid and sediment densities, and the sediment characteristics. The modes of motion may be sliding, rolling, or jumping (saltating).

From the point of view of engineering practice, the sediment transport rate that gives the amount of bed material transported by the flow is the most significant characteristic of the two-phase motion. As a consequence of this practical significance, a vast amount of transport formulae has been proposed by various researchers since the end of the last century.

For a particular ratio of densities of the sediment and the fluid, the modes of transport are generally believed to depend on the bed's average shear stress. For relatively shear stresses, the material is transported on or near the bed, called bed load. With further increase in shear, a part of the material is transported in a suspension state and called as suspended load. The total sediment transport rate is the sum of the bed load and the suspended load.

Many equations have been proposed for the prediction of the bedload transport rate. These equations are derived based on mostly experimental data and limited in situ measurements.

The bedload is essential for bed stability in the natural rivers and sediment dynamics as erosion, deposition, and scour around the hydraulic structures. Bed material at the upstream part of the rivers or streams with small and mesoscale watershed usually has gravel bed sediment texture. The gravel bed material diameter varies between $8 \mathrm{~mm}$ to $2 \mathrm{~mm}$, including sand materials between 0.05 $2 \mathrm{~mm}$. This large graduation and random replacement of the materials reduce the correct and sensitive prediction of the bedload. Therefore, probabilistic ways always have an advantage regarding the deterministic approaches. Usually, measurements about the bedload in the streams are always limited and have low quality because of the difficulties. However, Goodwin Creek bedload data kind of testbed for gravel-bed rivers and measurements with long term and so many hydrologic and hydraulic conditions such as base flows, rising and falling limbs of the floods. These data were supplied from Khunle and some other researchers since 1981.

The motion of sediment particles on the bed of the stream as bed load can be described as a stochastic process composed of alternating transport and rest periods (Shen, 1971). In other words, a grain moves in steps followed by periods of rest during which it remains motionless. Both the step length $\mathrm{X}$ and rest period $\mathrm{T}$ are random variables that change unpredictably. Therefore, bedload transport is a stochastic process, and the rate of 
transport fluctuates in time around an absolute value (Bayazit, 2000).

It is a complex issue to estimate the amount of bedload sediment yielded in rivers as it is natural. For this reason, several methods and formulas have been proposed to calculate the sediment transport rate as a function of the watershed, sediment, and flow characteristics. The total sediment rate in rivers is a combination of bedload, saltation, and suspended load (Bayazit, 1996).

Sediment yield estimates are required for a wide range of problems such as erosion/deposition, contamination in rivers, reservoirs, lakes, and coastal regions. This makes sediment yield estimation and transport calculations important and motivates many researchers for years to collect better data from the field and make more accurate predictions by developing various tools and methods (Morris and Fan, 1998; Algan et al., 1999-2002; Gomez, 2006; Diplas et al., 2008; Kironoto and Yulistiyanto, 2016; Aldabash and Balık Şanlı, F. 2016; Schäfer et al., 2019; Uzor-totty and Oyegun, C. 2020).

The developments in computer algorithms and the resolution power increase prompted researchers to use computer tools that they verified with field measurements. Many studies have been published especially on estimating sediment amount with the ANN technique and verifying this with a data set. In these publications, the predictive accuracy relationships between newly developed ANN algorithms and algorithms were examined. The ANN method is used not only in estimating sediment flow but also in defining all mechanisms and relationships in sediment formation and transport processes such as in river flow prediction (Sezin and Johnson, 1999; Khalil et al., 2001; Birikundavyi et al., 2002; Elshorbagy and Simonovic, 2002; Cigizoglu, 2003a; Cigizoglu, 2003b; Cigizoglu and Kisi, 2005), in rainfall estimations and rainfallrunoff connexion (Hsu et al., 1995; Minns and Hall, 1996; Fernando and Jayawardena, 1998; Silverman and Dracup, 2000; Dawson and Wilby, 2001; Kerem Cigizoglu and Alp, 2004; Freiwan and Cigizoglu, 2005; Abhishek et al., 2012; Samantaray et al., 2020; Pham et al., 2020), rain-induced flood prediction (Campolo et al., 2003; Rahman and Alias, 2001; Duncan et al., 2012; Menteş et al., 2019; Menegbo, 2019; Kabari, 2020).

ANN applications in sediment yield estimations and sediment transport modelling are relatively new compared to other water resources research areas but are still a topic that has been studied by a considerable number of researchers (Abrahart and White, 200; Nagy et al., 2002; Cigizoglu, 2003c; Tayfur and Guldal, 2006; Zhu et al., 2007; Sokouti, 2013; Kushwaha, 2017; Malik et al., 2017; Kushwaha, 2018; Gajbhiye et al., 2020). The prediction of bedload transport, especially of gravel grade bedding material, is extremely challenging. Estimation methods based on suspended material rate can give approximate values in this regard (Asheghi and Hosseini, 2020; Ashley et al., 2020).

\section{Artificial Neural Networks \\ The radial basis function-based neural networks (RBF)}

RBF networks were introduced into the neural network literature by Broomhead and Lowe (Broomhead and Lowe, 1988). The RBF network model is motivated by the locally tuned response observed in biological neurons. Neurons with a locally tuned response characteristic can be found in several parts of the nervous system, for example, cells in the visual sensitive cortex to bars oriented in a specific direction or other visual features within a small region of the Visual field (Poggio and Girosi, 1990). These locally tuned neurons show response characteristics bounded to a small range of the input space. The theoretical basis of the RBF approach lies in the field of interpolation of multivariate functions. The objective of interpolating a set of tuples $\left(x^{s}, y^{s}\right)_{s=1}^{N}$ with $\mathrm{xs} \in \mathrm{Rd}$ is to find a function $\mathrm{F}: \mathrm{Rd} \rightarrow \mathrm{R}$ with $\mathrm{F}(\mathrm{xs})=\mathrm{ys}$ for all $\mathrm{s}=1, \ldots, \mathrm{N}$ where $\mathrm{F}$ is a function of a linear space. In the RBF approach, the interpolating function $\mathrm{F}$ is a linear combination of basic functions

$F(x)=\sum_{s=1}^{N} w_{s} \phi\left(\left\|x-x^{s}\right\|\right)+p(x)$

Where $\|$.$\| denotes Euclidean norm, w1, .., wN are real$ numbers, $\phi$ a real-valued function, and $p \in \prod_{n}^{d} a$ polynomial of degree at most $\mathrm{n}$ (fixed in advance) in $d$ variables. The interpolation problem is to determine the real coefficients and the polynomial term $p=\sum_{l=1}^{D} a_{1} p_{j}$, where $\mathrm{p} 1, \ldots, \mathrm{pD}$ is the standard basis of $\prod \mathrm{n}^{\wedge} \mathrm{D} \mathrm{a} 1, \ldots, \mathrm{aD}$ are real coefficients.

The interpolation conditions are and

$F\left(x^{s}\right)=y^{s}, \quad \mathrm{~s}=1, \ldots, \mathrm{N}$

and

$\sum_{s=1}^{N} w_{s} p_{j}\left(x^{s}\right)=0, \quad \mathrm{j}=1, \ldots, \mathrm{D}$

The function $\phi$ is called a radial basis function if the interpolation problem has a unique solution for any choice of data points. In some cases, the polynomial term in equation (2) can be omitted and by combining it with equation (3), we obtain

$\phi \mathrm{w}=\mathrm{y}$

where $\mathrm{w}=(\mathrm{w} 1, \ldots, \mathrm{wN}), \mathrm{y}=(\mathrm{y} 1, \ldots, \mathrm{yN})$, and $\phi$ is a $\mathrm{N} \mathrm{x}$ $\mathrm{N}$ matrix defined by

$\phi=\left(\phi\left(\left\|x^{k}-x^{s}\right\|\right)\right)_{k, s=1, \ldots, N}$

Provided the inverse of $\phi$ exists, the solution $w$ of the interpolation problem can be explicitly calculated and has the form; $\mathrm{w}=\phi-1 \mathrm{y}$. The most popular and widely used radial basis function is the Gaussian basis function

$\phi(\|x-c\|)=e^{-\left(\|x-c\| / 2 \sigma^{2}\right)}$ 
with a peak at center $\mathrm{c} \in \mathrm{Rd}$ and decreasing as the distance from the center increases.

The solution of the exact interpolating RBF mapping passes through every data point (xs, ys). In the presence of noise, the interpolation problem's exact solution is typically a function oscillating between the given data points. An additional problem with the exact interpolation procedure is that the number of basic functions equal to the number of data points, and so calculating the inverse of the $\mathrm{NxN}$ matrix $\phi$ becomes intractable in practice. The interpretation of the RBF method is an artificial neural network consists of three layers: a layer of input neurons feeding the feature vectors into the network; a hidden layer of RBF neurons, calculating the outcome of the basic functions; and a layer of output neurons, calculating the outcome of the basic functions, and a layer of output neurons, calculating a linear combination of the basic functions (Taurino et al., 2003). The different number of hidden layer neurons and spread frequently were tried in the study.

\section{The Generalized Regression Neural Networks (GRNN)}

The basics of the GRNN can be obtained in the literature (Specht, 1991; Tsoukalas and Uhrig, 1996). The GRNN consists of four layers: an input layer, pattern layer, summation layer, and output layer. The number of input units in the first layer is equal to the total number of parameters, including from one to six previous daily flows. The first layer is fully connected to the second, pattern layer, where each unit represents a training pattern, and its output is a measure of the distance of the input from the stored patterns. Each pattern layer unit is connected to the two neurons in the summation layer: the $\mathrm{S}$-summation neuron and the D-summation neuron. The S-summation neuron computes the pattern layer's weighted outputs while the D-summation neuron calculates the pattern neurons' unweighted outputs. The connection weight between the ith neuron in the pattern layer and the S-summation neuron is $\mathrm{y} 1$; the target output value corresponding to the $\mathrm{i}^{\text {th }}$ input pattern. For the D-summation neuron, the connection weight is unity. The output layer merely divides the output of each Ssummation neuron by that of each D-summation neuron, yielding the predicted value to an unknown input vector $\mathrm{x}$ as

$\hat{y}(x)=\frac{\sum_{i=1}^{n} y_{i} \exp \left[-D\left(x, x_{i}\right)\right]}{\sum_{i=1}^{n} \exp \left[-D\left(x, x_{i}\right)\right]}$

where $\mathrm{n}$ indicates the number of training patterns and the Gaussian D function in (7) is defined as

$D\left(x, x_{i}\right)=\sum_{j=1}^{p}\left(\frac{x_{j}-x_{i j}}{\zeta}\right)^{2}$

where $\mathrm{p}$ indicates the number of elements of an input vector. The $\mathrm{x}_{\mathrm{j}}$ and $\mathrm{x}_{\mathrm{ij}}$ represent the $\mathrm{jth}$ element of $\mathrm{x}$ and $\mathrm{xi}$, respectively. The $\zeta$ is generally referred to as the spread factor, whose optimal value is often determined experimentally. The larger that spread is, the smoother the function approximation will be. Too large a spread means many neurons will be required to fit a fastchanging function. Too small a spread means many neurons will be required to fit a smooth function, and the network may not generalize well. In this study, different spreads were tried to find the best one that gave the minimum MSE for a given problem.

Using the GRNN and RBF methods, sediment load estimation is studied by comparing the measurements in various river beds, either separately or comparatively (Feyzolahpour et al., 2012; Safari et al., 2013; Buyukyildiz and Kumcu, 2017).

\section{Analysis of Data}

In this study, the flow characteristics and bedload data belonging to Goodwin Creek in the USA are employed. Goodwin Creek is located in the USA, Mississippi, and bedload data have been measured in the watershed since 1981 (Kuhnle et al., 2014). Goodwin Creek Watershed is located on the bluff-hills in the northern of the Mississippi, USA. This region is a relatively steep slope and has a wide range of erosion and sedimentation problems. The drainage area upstream of the data collected station is $17.9 \mathrm{~km}^{2}$. The stream section of the measuring station is approximately $25 \mathrm{~m}$ wide and $3.0 \mathrm{~m}$ deep. The bed material's surface layer has a median grain size of $11.73 \mathrm{~mm}$, while the corresponding subsurface value is $8.31 \mathrm{~mm}$. The average bed slope of the creek section of this station is 0.0033 (Kuhnle, 1992).

The data belonging to the flow characteristics include flume depth, flow discharge, hydraulic radius, water surface slope, bed shear stress, and Froude number values. The bed load data were measured at the same time as flow characteristics data. The cross-correlations between each flow discharge and total sediment load are given in Figure 1.

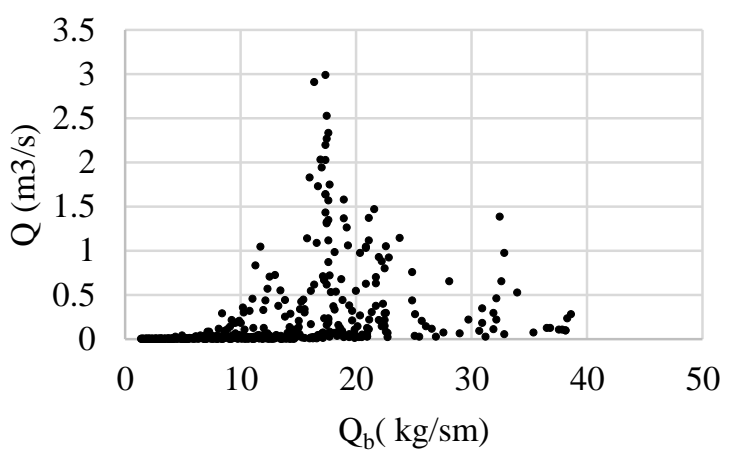

Figure 1. Goodwin Creek discharge vs. total sediment load

\section{Application of ANNs to bedload data}

In this study, algorithms written in MATLAB RBF and GRNN were employed for ANN simulations. The ANN network structure consisted of three layers. i.e., input laser, single hidden layer, and output layer. The input layer was prepared using flow characteristics like flume 
depth, flow discharge, hydraulic radius, water surface slope, bed shear stress, and Froude number. The application of the ANN's to time series data consisted of two steps. The first step was the training of the neural networks. This included flow characteristics describing the input and sediment load data describing the output to the network to obtain the interconnection weights. Once the training stage was completed, the ANNs were applied to the testing data. Over 400 hours long data were used for analysis, the last 340 data to train the networks and the first 100 to test it. Determining a neural network's appropriate architecture for a particular problem is essential since the network topology directly affects its computational complexity and generalization capability.

The network structure provides the best training result, i.e., the lowest mean square error (MSE), which was employed for the testing stage. For RBF and GRNN, the same input layer structure was employed. The spread parameter providing the best performance criteria was found equal to 0.07 for RBF and 0.015 for GRNN. The iteration number was taken as equal to 20 for $\mathrm{RBF}$ simulations. The input and output data were scaled between 0.1 and 0.9 to overcome upper-limit and lowerlimit saturation problems. The performance evaluation measures were the mean square error (MSE) and the coefficient of determination (R2) between estimated and observed bed sediment loads. Conventional multilinear regression was also applied to the same data for comparison.

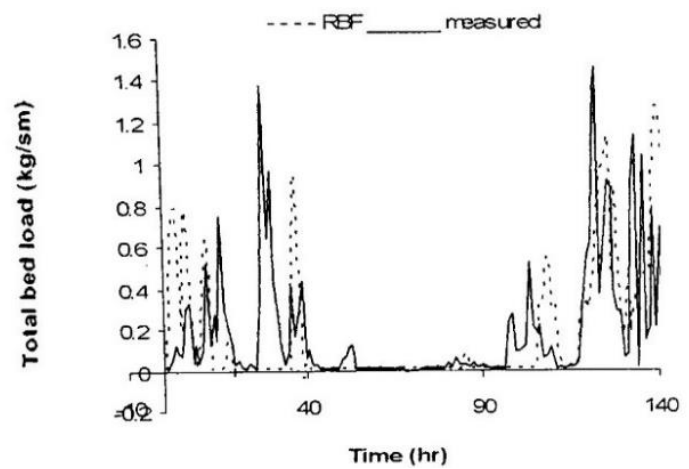

Figure 1. Total bed load estimation results using RBI for the testing period
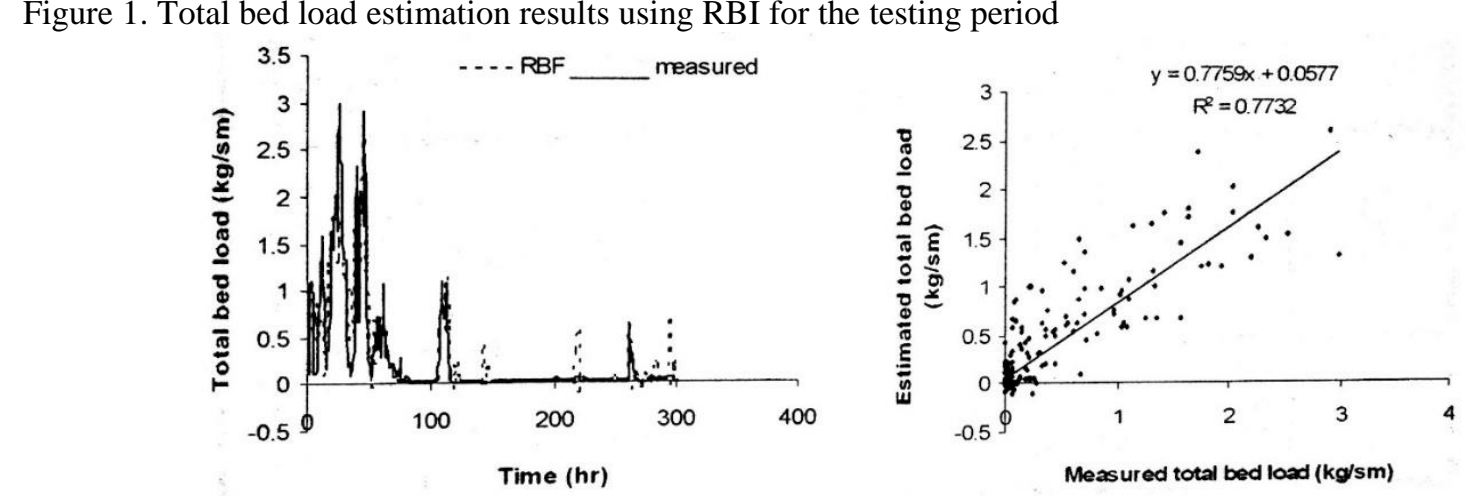

Figure 2. Total bed load estimation results using RBI for the training period

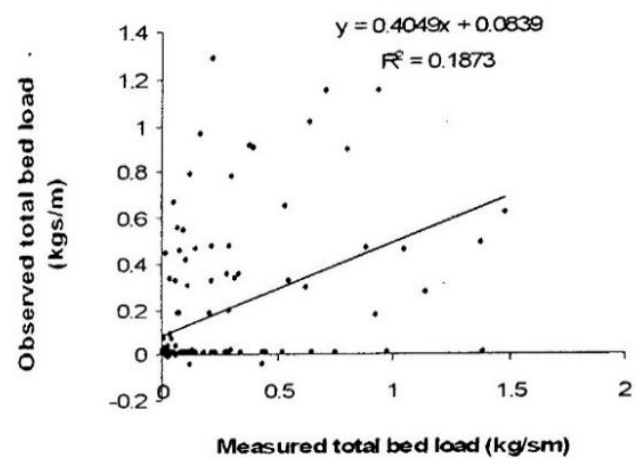

\section{Total Bed load simulation results}

The ANN simulations were carried out using RBF and GRNN methods. The results for the training and testing period are shown in Figure 1 - Figure 4. It was seen that though the results for the training period are convincing (Figure 2 and Figure 4), the ANN estimations for the testing measurements are not so satisfactory. The multilinear regression (MLR) estimates for the testing period are far from the regression line, and the MLR could not capture the general behaviour of the total bedload series and the other two ANN methods. The $\mathrm{R}^{2}$ value for the calibration (training) period of MLR (0.63) is lower compared with RBF and GRNN (0.77 and 0.84, respectively). The GRNN method did not generate negative estimates different from the RBF and MLR methods. This is expected since the GRNN estimates are bounded between the extreme values of the training data. The estimation study is extended for the total gravel bedload and the total sand bedload measurements. The gravel load values are measured, and the difference between total bedload and gravel load provides the sand load values. The ANN estimations for the gravel and sand load are compared with MLR estimations in Figure 6 - Figure 15. In general, two ANN methods provide more reasonable estimations for gravel and sand load measurements compared with MLR results. Estimations for gravel seem to be closer concerning those for the sand load. 

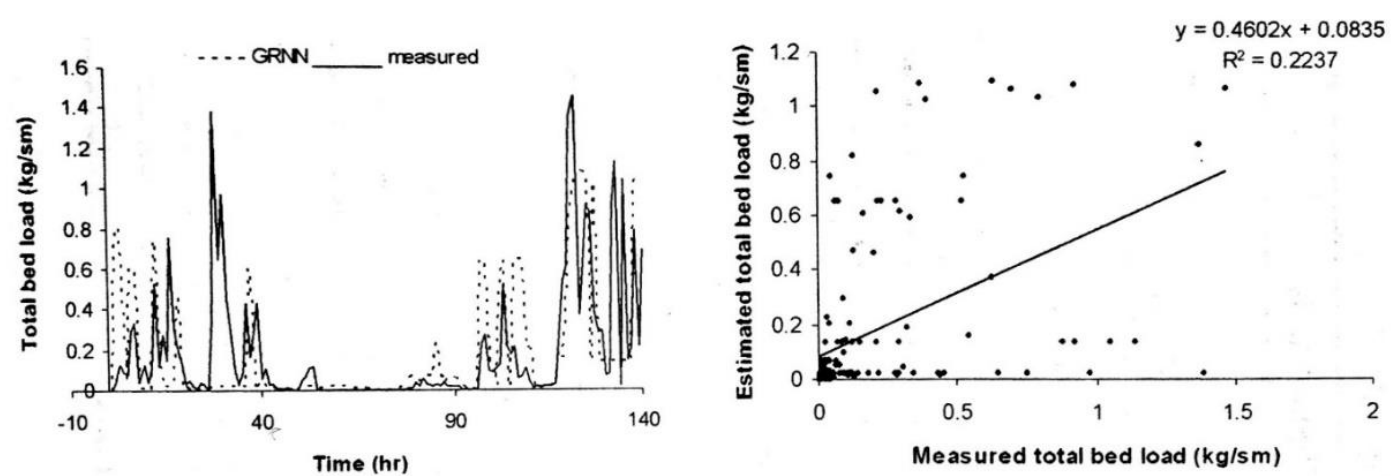

Figure 3. Total bed load estimation results using GRNN for the testing period
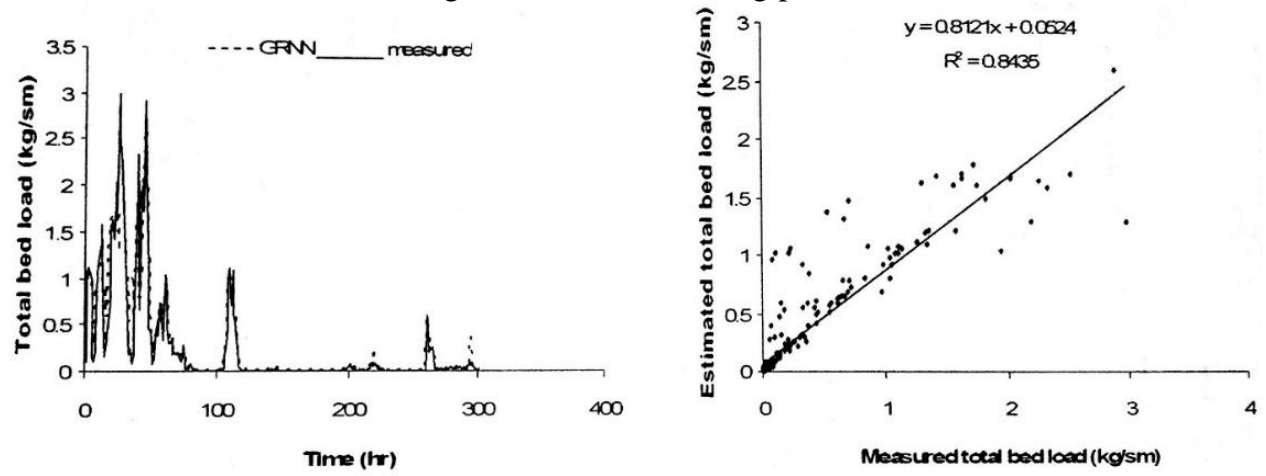

Figure 4. Total bed load estimation results using GRNN for the training period

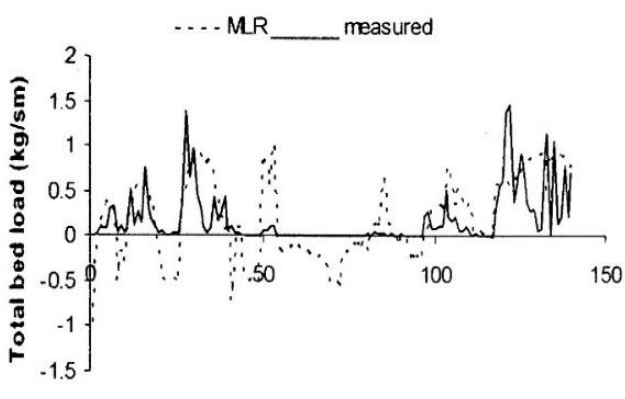

Time (hr)

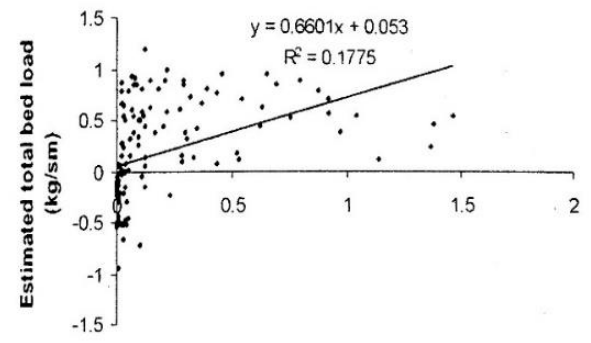

Measured total bed load $(\mathrm{kg} / \mathrm{sm})$

Figure 5. Total bed load estimation results using MLR for the testing period
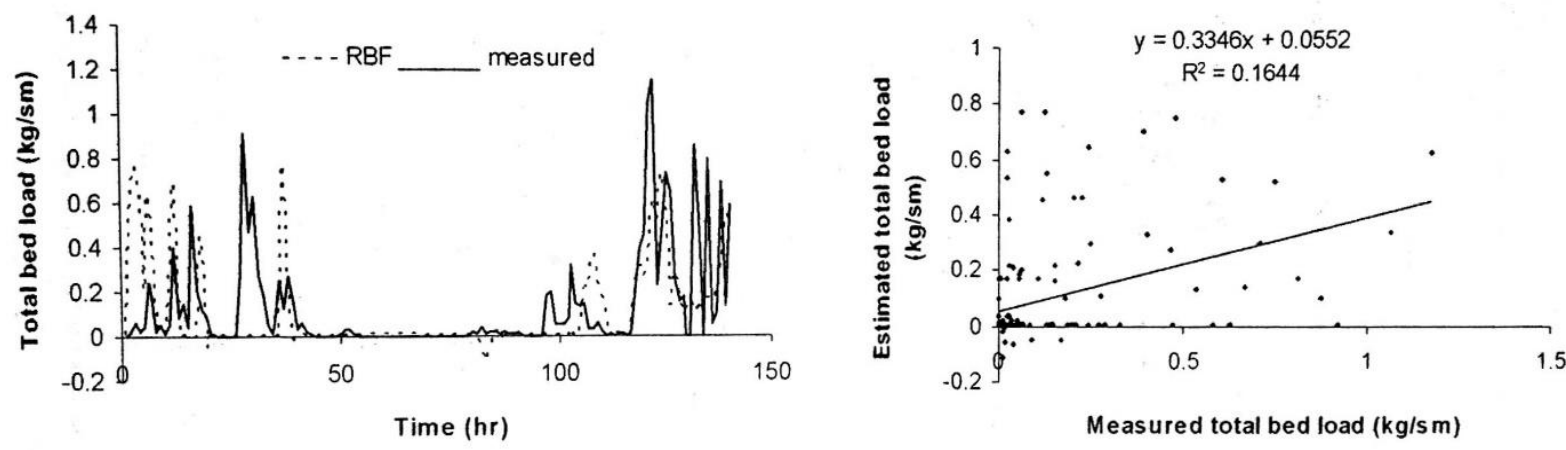

Figure 6. Total gravel bed load estimation results using RBF for the testing period

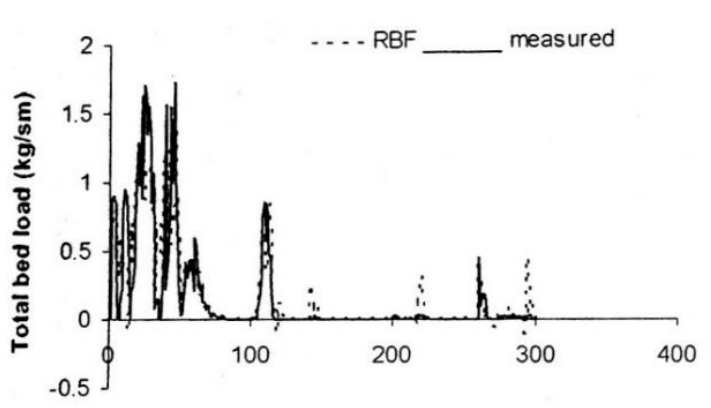

Time (hr)

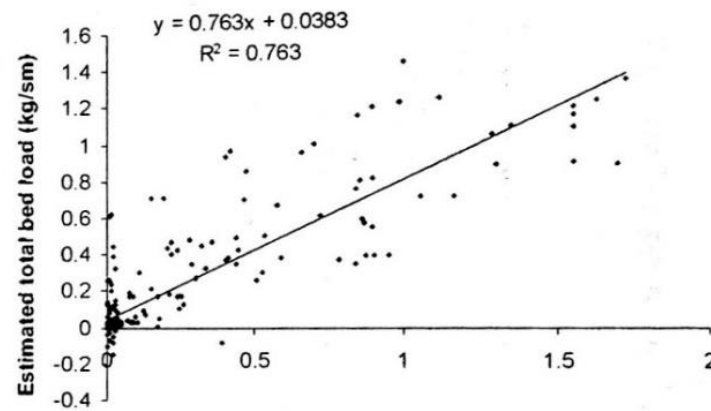

Meas ured total bed load $(\mathrm{kg} / \mathrm{s} \mathrm{m})$ 
Figure 7. Total gravel bed load estimation results using RBF for the training period
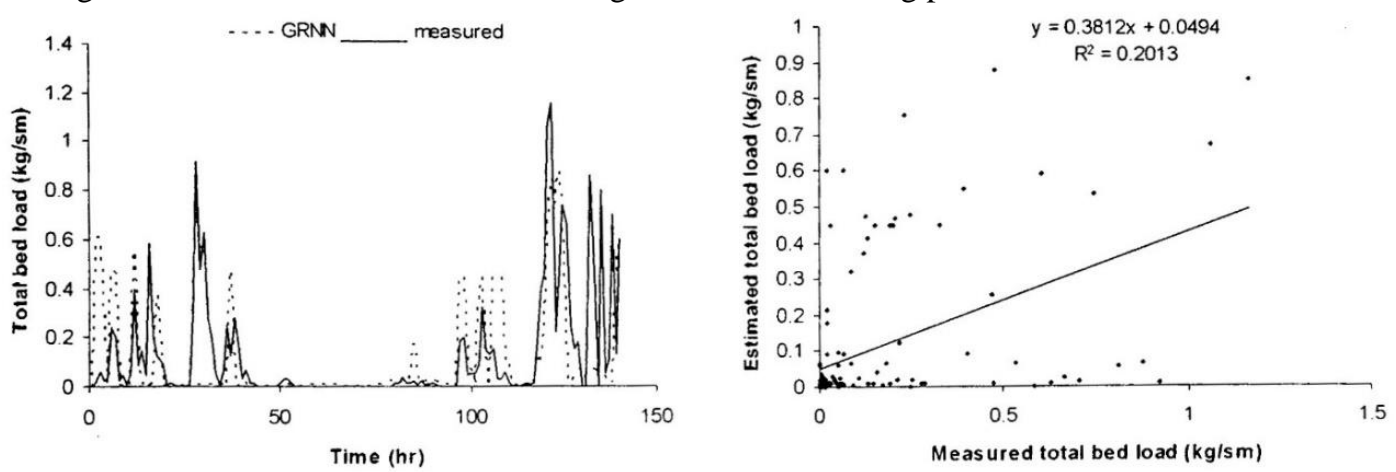

Figure 8. Total gravel bed load estimation results using GRNN for the testing period
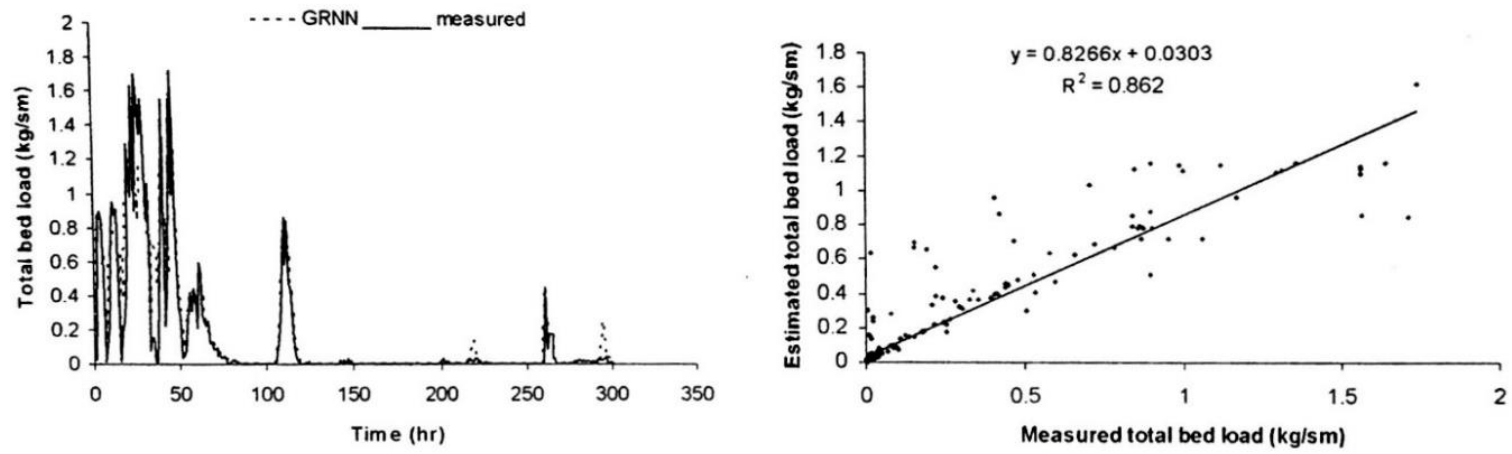

Figure 9. Total gravel bed load estimation results using GRNN for the training period

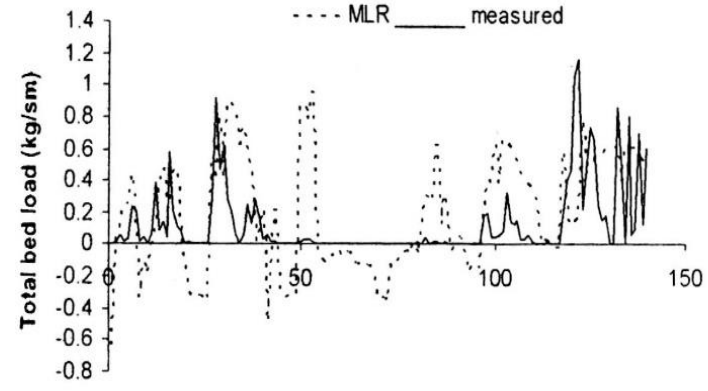

Time (hr)

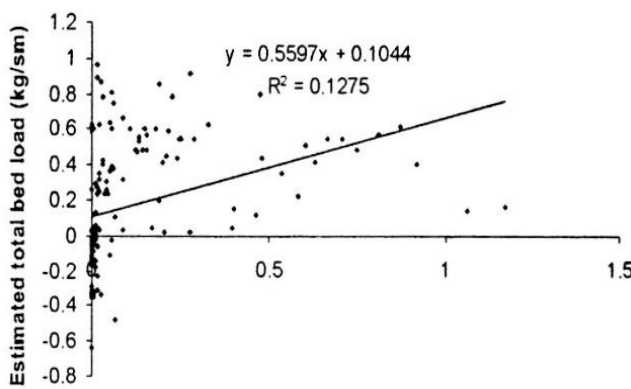

Me asured total bed load $(\mathrm{kg} / \mathrm{sm})$

Figure 10. Total gravel bed load estimation results using MLR for the testing period
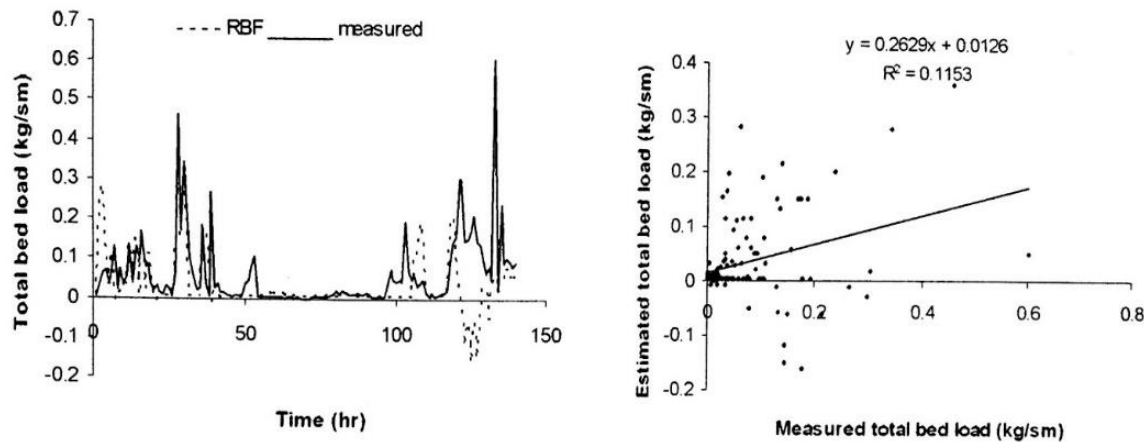

Figure 11. Total sand bed load estimation results using RBF for the testing period 

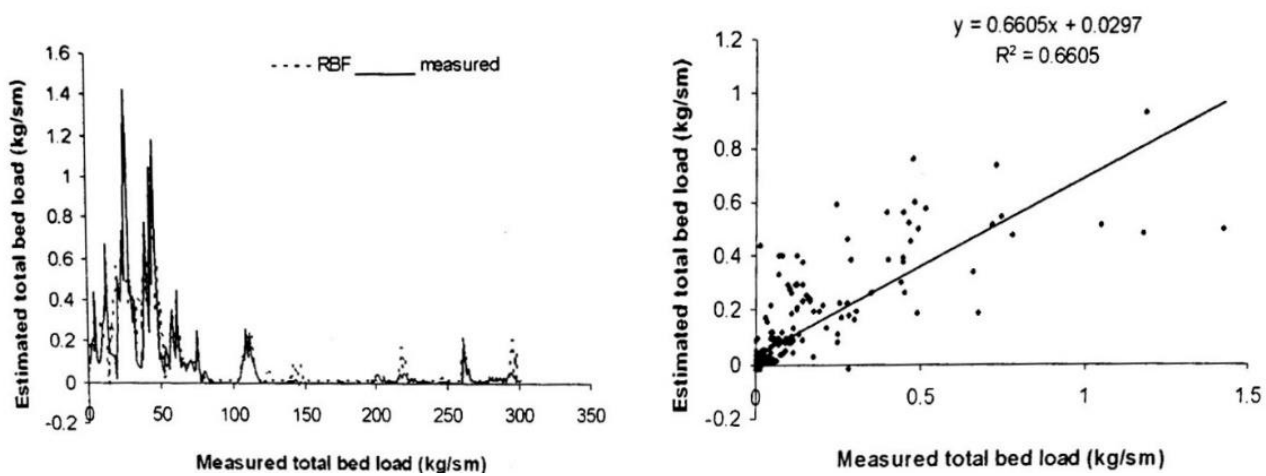

Figure 12. Total sand bed load estimation results using RBF for the training period
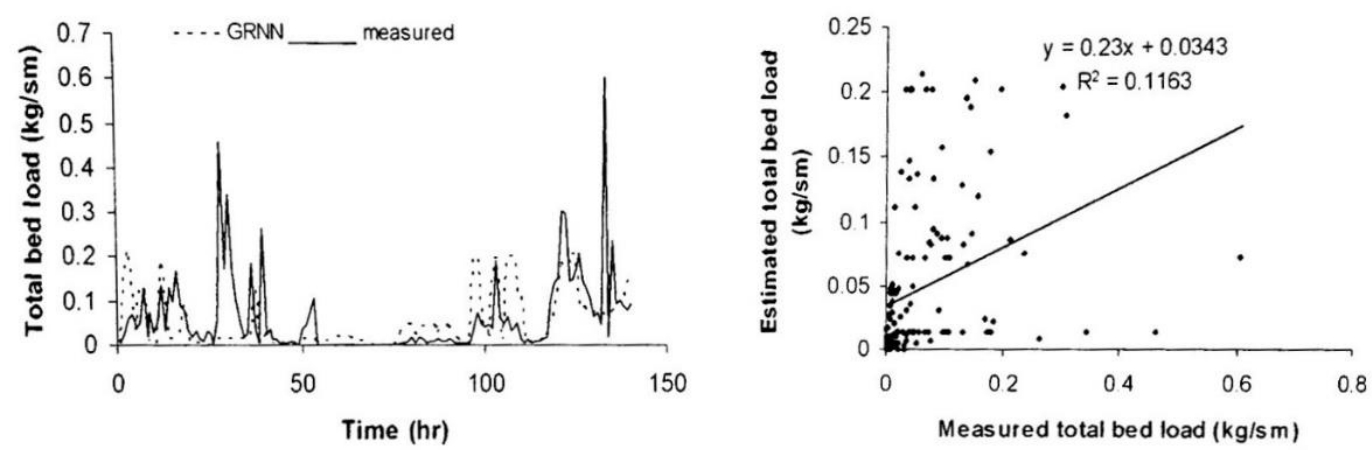

Figure 13. Total sand bed load estimation results using RBF for the testing period
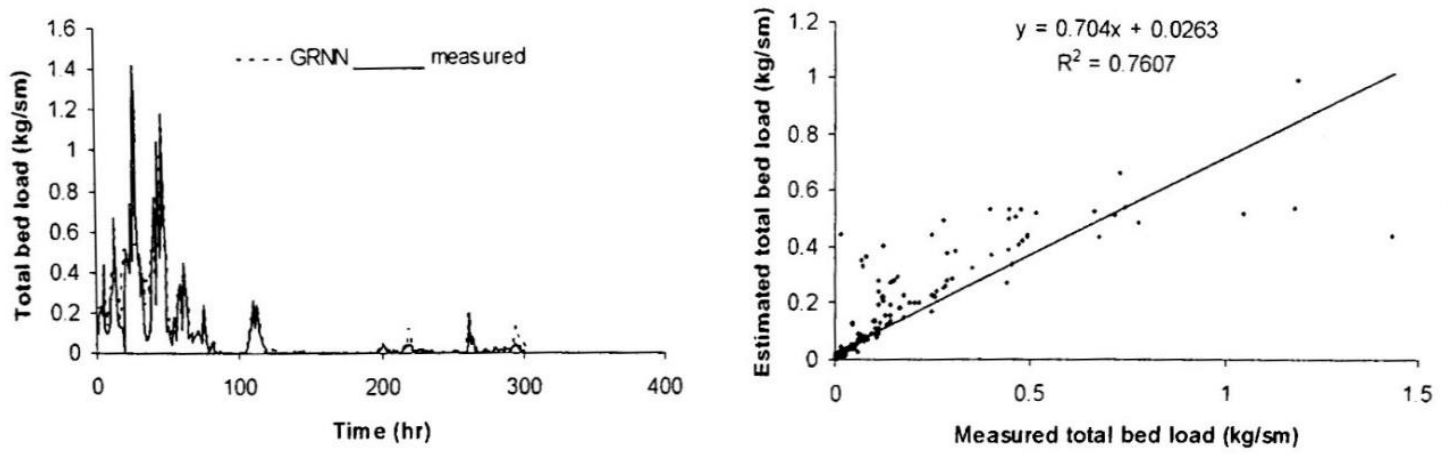

Figure 14. Total sand bed load estimation results using GRNN for the training period
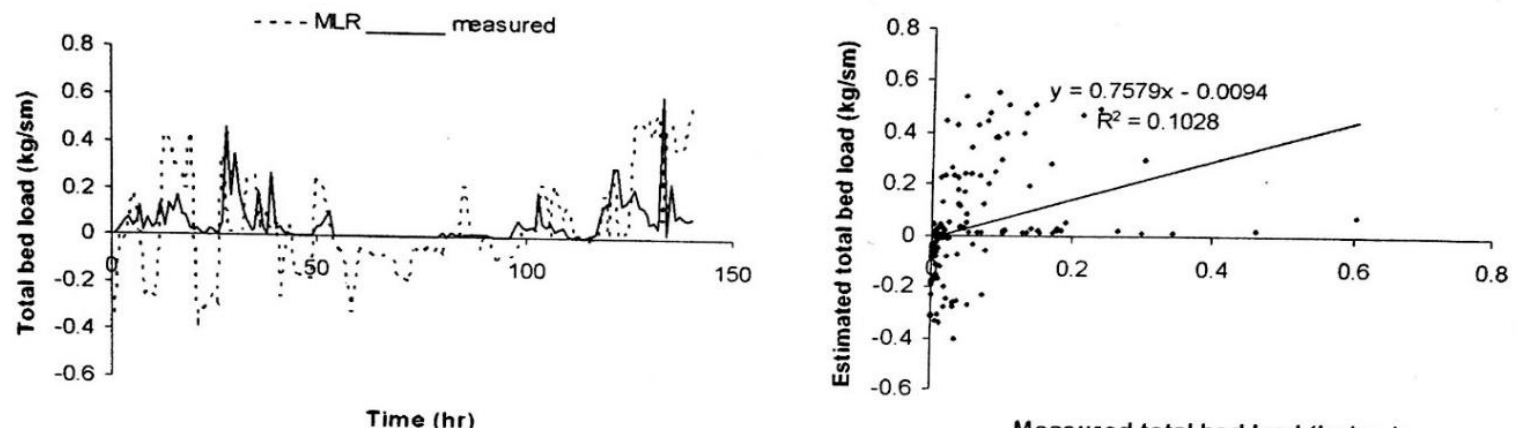

Measured total bed load (kg/sm)

Figure 15. Total sand bed load estimation results using MLR for the testing period.

\section{Results and Conclusion}

When ANN results were examined, it was seen that GRNN and RBF models gave good results for the sand bed transport estimations. However, for gravel bed material transport estimations, only the GRNN model could produce compatible results with measurements. The adaptation in the models is better for non-flood cases, but the correlation of the models with the measurements decreases when a flood occurs. In case of flood, the stream transports more sediment than usual and forms an armour layer at the bed. This causes misleading model estimations.

Total, sand and gravel sediment loads were estimated by using various ANN models. Estimation of bedload 
transport is challenging due to the complexity of the natural phenomenon itself. Bedload transport rate depends on quite a lot of parameters and variables.

The models work better for sand bed load estimation because of the direct proportion between sand bedload and flow rate. Especially for sand bedload, GRNN and RBF models computed acceptable results in estimations as well as flood conditions (Figure 13 and Figure 15). In gravel bedload estimations, unfortunately, only the GRNN model calculated acceptable results (Figure 10). In contrast, the ANN, especially GRNN and RBF models, are applicable to estimate bed load and worth improving.

\section{References}

Abhishek, K., Kumar, A., Ranjan, R., Kumar, S. (2012). A rainfall prediction model using artificial neural network. In Proceedings - 2012 IEEE Control and System Graduate Research Colloquium, ICSGRC 2012. DOI: 10.1109/ICSGRC.2012.6287140.

Abrahart, R. J., White, S. M. (2001). Modelling sediment transfer in Malawi: Comparing backpropagation neural network solutions against a multiple linear regression benchmark using small data sets. Physics and Chemistry of the Earth, Part B: Hydrology, Oceans and Atmosphere, 26(1), 19-24. DOI: 10.1016/S1464-1909(01)85008-5.

Aldabash, M., Balık Şanlı, F. (2016). Analysis of Multi Temporal Satellite Imagery for Total Suspended Sediments in a Wave-Active Coastal Area-Gaza Strip Coastal Water, Palestine. International Journal of Environment and Geoinformatics, 3(1), 1-11 . DOI: 10.30897/ijegeo.304414.

Algan O, Gazioğlu C, Çağatay N, Yücel ZY, Gönençgil B. (1999). Sediment and water influxes into the Black Sea by Anatolian rivers. Zeitschrift für Geomorphologie 43: 61-79.

Algan, O., Gökasan, E., Gazioglu, C., Yücel, ZYY., Alpar, b., Güneysu, C., Kirci, E., Demirel, S., Sari, E., Ongan, D. (2002). A high-resolution seismic study in Sakarya Delta and submarine Canyon, southern Black Sea shelf, Continent. Shelf Res.,22(10), 1511-1527.

Asheghi, R., Hosseini, S. A. (2020). Prediction of bed load sediments using different artificial neural network models. Frontiers of Structural and Civil Engineering, 14(2), 374-386. DOI: 10.1007/s11709019-0600-0.

Ashley, T., McElroy, B., Buscombe, D., Grams, P. E., Kaplinski, M. (2020). Estimating Bedload From Suspended Load and Water Discharge in Sand Bed Rivers. Water Resources Research, 56. DOI: 10.1029/2019WR025883.

Bayazit, M. (1996). Mechanism of Sediment Transport. In Post-Graduate Course in Sediment Transport Technology (pp. 5-19).

Bayazit, M. (2000). Sediment Transport Technology. Bed Metarial Transport.

Birikundavyi, S., Labib, R., T. Trung, H., Rousselle, J. (2002). Performance of Neural Networks in Daily Streamflow Forecasting. In Journal of Hydrologic
Engineering - J HYDROL ENG (Vol. 7). DOI: 10.1061/(ASCE)1084-0699(2002)7:5(392).

Broomhead, D. S., Lowe, D. G. (1988). Multivariable Functional Interpolation and Adaptive Networks. Complex Systems, 2, 321-355.

Buyukyildiz, M., Kumcu, S. Y. (2017). An Estimation of the Suspended Sediment Load Using Adaptive Network Based Fuzzy Inference System, Support Vector Machine and Artificial Neural Network Models. Water Resources Management, 31(4), 13431359. DOI: $10.1007 / \mathrm{s} 11269-017-1581-1$.

Campolo, M., Soldati, A., Andreussi, P. (2003). Artificial neural network approach to flood forecasting in the River Arno. Hydrological Sciences Journal-Journal Des Sciences Hydrologiques HYDROLOG SCI J, 48, 381-398. DOI: 10.1623/hysj.48.3.381.45286.

Cigizoglu, H. K. (2003a). Incorporation of ARMA models into flow forecasting by artificial neural networks. Environmetrics, 14(4), 417-427. DOI: 10.1002/env.596.

Cigizoglu, H. K. (2003c). Estimation and forecasting of daily suspended sediment data by multi-layer perceptrons. Advances in Water Resources, 27(2), 185-195. DOI: 10.1016/j.advwatres.2003.10.003.

Cigizoglu, H.K., Kisi, O. (2005). Flow prediction by three back propagation techniques using $\mathrm{k}$-fold partitioning of neural network training data. Nordic Hydrology, 36(1), 49-64. DOI: 004/165/004165223.

Cigizoglu, H Kerem, Alp, M. (2004). Rainfall-Runoff Modelling Using Three Neural Network Methods BT - Artificial Intelligence and Soft Computing - ICAISC 2004 (L. Rutkowski, J. H. Siekmann, R. Tadeusiewicz, \& L. A. Zadeh (eds.); pp. 166-171). Springer Berlin Heidelberg..

Cigizoglu, H. K. (2003b). Estimation, forecasting and extrapolation of river flows by artificial neural networks. Hydrological Sciences Journal, 48(3), 349-362. DOI: 10.1623/hysj.48.3.349.45288.

Dawson, C. W., Wilby, R. L. (2001). Hydrological modelling using artificial neural networks. Progress in Physical Geography, 25(1), 80-108. DOI: 10.1191/030913301674775671.

Diplas, P., Kuhnle, R., Gray, J., Glysson, D., Edwards, T. (2008). Sediment Transport Measurements (pp. 307-353). DOI: 10.1061/9780784408148.ch05.

Duncan, A., Chen, A., Keedwell, E., Djordjević, S., Savic, D. (2012). Urban flood prediction in real-time from weather radar and rainfall data using artificial neural networks. In IAHS-AISH Publication (Vol. 351).

Elshorbagy, A., Simonovic, S. (2002). Estimation of missing streamflow data using principles of chaos theory. In Journal of Hydrology - J HYDROL (Vol. 255). DOI: 10.1016/S0022-1694(01)00513-3.

Fernando, D. A. K., Jayawardena, A. (1998). Runoff forecasting using RBF networks with OLS algorithm. In Journal of Hydrologic Engineering - J HYDROL ENG (Vol. 3). DOI: 10.1061/(ASCE)10840699(1998)3:3(203).

Feyzolahpour, M., Rajabi, M., Roostaei, S. (2012). Estimating suspended sediment concentration using neural differential evolution (NDE), multi layer 
perceptron (MLP) and radial basis function (RBF) models. International Journal of the Physical Sciences, 7. DOI: 10.5897/IJPS12.269.

Freiwan, M., Cigizoglu, H. (2005). Prediction of total monthly rainfall in Jordan using feed forward backpropagation method. In Fresenius Environmental Bulletin (Vol. 14).

Gajbhiye, S., Singh, V., Kisi, O., Khosrowshahi, V., Meshram, C. (2020). Application of Artificial Neural Networks, Support Vector Machine and Multiple Model-ANN to Sediment Yield Prediction. Water Resources Management, 34. DOI: 10.1007/s11269020-02672-8.

Gomez, B. (2006). The Potential Rate of Bed-Load Transport. Proceedings of National Academy of Sciences, 103.

Hsu, K., Vijai Gupta, H., Sorooshian, S. (1995). Artificial Neural Network Modeling of the RainfallRunoff Process. In Water Resources Research WATER RESOUR RES (Vol. 31). DOI: 10.1029/95WR01955.

Rahman, I. I. A., Alias, N. M. A., (2011). Rainfall forecasting using an artificial neural network model to prevent flash floods. 8th International Conference on High-Capacity Optical Networks and Emerging Technologies, 323-328. DOI: 10.1109/HONET.2011.6149841.

Kabari, L. (2020). Rain-Induced Flood Prediction for Niger Delta Sub-Region of Nigeria Using Neural Networks. European Journal of Engineering Research and Science, 5, 1124-1130. DOI: 10.24018/ejers.2020.5.9.2114.

Khalil, M., Panu, U., Lennox, W. C. (2001). Groups and neural networks based streamflow data infilling procedures. In Journal of Hydrology. 241. DOI: 10.1016/S0022-1694(00)00332-2.

Kironoto, B., Yulistiyanto, B. (2016). The Simplified of Suspended Sediment Measurement Method for Predicting Suspended Sediment Load as a Basic of Reservoir Capacity Design as Renewable Energy Resource. International Journal of Renewable Energy Research, 6, 315-322.

Kuhnle, R. A. (1992). Fractional transport rates of bed load on Goodwin Creek. In Dynamics of Gravel Bed Rivers.

Kuhnle, R. A., Wren, D. G., Langendoen, E. J. (2014). Predicting bed load transport of sand and gravel on Goodwin Creek. Journal of Hydro-Environment Research, $\quad 8(2), \quad 153-163 . \quad$ DOI: 10.1016/j.jher.2013.11.005.

Kushwaha, D. (2017). Modeling suspended sediment concentration using multilayer feedforward artificial neural network at the outlet of the watershed. International Journal Of Agricultural Engineering, 10, 302-313. DOI: 10.15740/HAS/IJAE/10.2/302313.

Kushwaha, D. (2018). Modeling suspended sediment concentration using multi-layer feedforward artificial neural network at the outlet of the watershed. 10. DOI: 10.15740/HAS/IJAE/10.

Malik, A., Kumar, A., Piri, J. (2017). Daily suspended sediment concentration simulation using hydrological data of Pranhita River Basin, India. Computers and
Electronics in Agriculture, 138, 20-28. DOI: 10.1016/j.compag.2017.04.005.

Menegbo, E. (2019). Locational Analysis of Surface Water Quality, Sediment and Dredge Spoil At Nembe, Bayelsa State, Nigeria, International Journal of Environment and Geoinformatics, 6(1), 15-21. DOI: $10.30897 /$ ijegeo.464593.

Menteş, E., Kaya, Ş., Tanık, A., Gazioğlu, C. (2019). Calculation of Flood Risk Index for Yesilirmak Basin-Turkey. International Journal of Environment and Geoinformatics, 6(3), 288-299.DOI: 10.30897/ijegeo.661533.

Minns, A. W., Hall, M. J. (1996). Modélisation pluiedébit par des réseaux neuroneaux artificiels. Hydrological Sciences Journal, 41(3), 399-417. DOI: 10.1080/02626669609491511.

Morris, G. L., Fan, J. (1998). Reservoir Sedimentation Handbook. McGraw-Hill Book Co, 7(11), 956-963. DOI: 10.1017/CBO9781107415324.004.

Nagy, H. M., Watanabe, K., Hirano, M. (2002). Prediction of Sediment Load Concentration in Rivers using Artificial Neural Network Model. Journal of Hydraulic Engineering, $128 . \quad$ DOI: 10.1061/(ASCE)0733-9429(2002)128:6(588).

Pham, B., Le, L., Le, T.-T., Bui, K.-T., Le, V., Ly, H.-B., Prakash, I. (2020). Development of advanced artificial intelligence models for daily rainfall prediction. Atmospheric Research, 237. DOI:10.1016/j.atmosres.2020.104845.

Poggio, T., Girosi, F. (1990). Networks for approximation and learning. Proceedings of the IEEE, 78(9), 1481-1497. DOI: 10.1109/5.58326.

Safari, M. J. S., Aksoy, H., Mohammadi, M. (2013). Application of ANN for the analysis of sediment incipient deposition in rigid boundary channels. DOI: 10.13140/2.1.5053.7764.

Samantaray, S., Tripathy, O., Sahoo, A., Ghose, D. (2020). Rainfall Forecasting Through ANN and SVM in Bolangir Watershed, India (pp. 767-774). DOI: 10.1007/978-981-13-9282-5_74.

Schäfer, S., Schalagenhauser, M., Rutschmann, P. (2019). Optical Measurement Method For Quantifying Sediment Transport In Physical Experiments. DOI: 10.3850/38WC092019-0409.

Sezin, T. A., Johnson, P. A. (1999). Rainfall-Runoff Modeling Using Artificial Neural Networks. Journal of Hydrologic Engineering, 4(3), 232-239. DOI: 10.1061/(ASCE)1084-0699(1999)4:3(232).

Shen, H. W. (1971). Chap 11. Wash Load and Bed Load. In River Mechanics Vol I.

Silverman, D., Dracup, J. A. (2000). Artificial Neural Networks and Long-Range Precipitation Prediction in California. Journal of Applied Meteorology - 39. DOI: $10.1175 / 1520-0450(2000) 039$.

Sokouti, R. (2013). Modeling sediment yield using artificial neural network and multiple linear regression methods. International Journal of Biosciences, 3, 116-122.

Specht, D. (1991). A General Regression Neural Network. In IEEE Transactions on Neural Networks (Vol. 2).

Taurino, A., Dello Monaco, D., Capone, S., Epifani, M., Rella, R., Siciliano, P., Ferrara, L., Maglione, G., 
Basso, A., \& Balzarano, D. (2003). Analysis of dry salami by means of an electronic nose and correlation with microbiological methods. In Sensors and Actuators B-chemical, 95. DOI: 10.1016/S09254005(03)00421-0.

Tayfur, G., Guldal, V. (2006). Artificial neural networks for estimating daily total suspended sediment in natural streams. Nordic Hydrology, 37, 69-79. https://doi.org/10.2166/nh.2005.031.

Tsoukalas, L. H., Uhrig, R. E. (1996). Fuzzy and Neural Approaches in Engineering (1st ed.). John Wiley \&amp; Sons, Inc.

Uzor-totty, A., Oyegun, C. (2020). Spatio-Temporal Dynamics of Sediment yield across the Imo River Basin South- East Nigeria, International Journal of Environment and Geoinformatics, 7(2), 184-190. DOI: 10.30897/ijegeo.645611.

Zhu, Y.-M., Lu, X. X., Zhou, Y. (2007). Suspended sediment flux modeling with artificial neural network: An example of the Longchuanjiang River in the Upper Yangtze Catchment, China. Geomorphology, 84, 111-125. DOI: 10.1016/j.geomorph.2006.07.010. 